\title{
Effect of Vapor Pressure on the Rate of Softening of Fish Bone by Super-Heated Steam Cooking
}

\author{
Masanobu Ishikawa, ${ }^{{ }_{1}}$ Makoto Kato, ${ }^{* 2}$ Tomoo Mihori, ${ }^{* 1}$ \\ Hisahiko Watanabe, ${ }^{* 1}$ and Yoshio Sakai*3 \\ (Received April 19, 1990)
}

\begin{abstract}
The softening process of fish bone was studied to utilize fish bone as a calcium source in human diet. To reduce the loss of soluble components of fish tissue during cooking, heating by super-heated steam was examined. Since drying of fish tissue might occur during super-heated steam cooking, the softening rate of mackerel spine and the moisture loss of mackerel meat cooked in super-heated steam were determined for samples cooked at $120^{\circ} \mathrm{C}$ and $130^{\circ} \mathrm{C}$ under pressures in the range from $1.2 \mathrm{kgf} \cdot \mathrm{cm}^{-2}$ to $2.7 \mathrm{kgf} \cdot \mathrm{cm}^{-2}$ (absolute pressure). The softening reaction conformed to an apparent first-order reaction. The softening rate constant apparently depended on the pressure of the super heated steam and not on the temperature of the steam. It is interpreted from the results that the temperature of the spine was the saturation temperature of the super-heated steam which depends only on the total pressure and is independent of the temperature of the super-heated steam. The softening rate constant was represented by an Arrhenius type equation as following: $\log (k)=12.2-5.96 \times 10^{3}\left(1 / T_{s}\right), k$ : the softening rate constant $\left(s^{-1}\right), T_{8}$ : the saturation temperature of the super-heated steam. The loss of moisture during cooking was small $(2.5 \%-$ $7.9 \%$.
\end{abstract}

Because bone disorder osteoporosis is acknowledged as a major public health problem, ${ }^{1}$ the market for calcium fortified products has been reported to be growing these days. ${ }^{2,33}$ The increase in the consumption of dairy products and other calcium-containing foods such as broccoli, tofu, oysters, and sardines was reported.) Among these calcium-containing foods, the authors have studied the utilization of fish bone as calcium source in human diet..$^{-8}$

In order to make fish bone edible, the softening kinetics of fish bone in hot water, ${ }^{5,8,8)}$ in hot acetic acid solutions, ${ }^{3,7,8)}$ and in green tea infusions ${ }^{8)}$ have studied. According to the results of the above cited studies, the required cooking time to make fish bone edible is considerably longer than the usual cooking time of fish meat; it takes several hours to soften the fish bone to be one tenth of the initial strength in hot water at temperatures lower than $100^{\circ} \mathrm{C}^{5,8,83}$ Under these cooking conditions, undesirable loss of soluble components of fish tissue can be conceivable. ${ }^{b-8)}$
The loss of soluble components of fish tissue during a hot water cooking will be minimized if a fish is cooked in "dry atmosphere"; e.g. roasting, broiling, or "super heated steam cooking (SHSC)" which is a cooking of food by direct contact with super-heated steam.

One of the drawback of cooking in "dry atmosphere" is unacceptable drying or scorching of food. This may be a crucial factor in cooking of fish bone, because the cooking of fish bone needs a long cooking time or a high temperature as mentioned above. In order to avoid excessive drying or scorching, control of the drying rate is necessary. Such control may be achieved by the use of SHSC, since we can vary the vapor pressure of water up to the saturation vapor pressurc.

Although "super-heated steam cooking" has potential usefulness, applications of this process ${ }^{102}$ and investigation into this process ${ }^{11}$ are scarce. Information is not available for the cooking rate of fish bone and the drying rate of fish tissue in super-heated steam. In the present study, we

*1 Department of Food Science and Technology, Tokyo University of Fisheries, Konan, Minato,

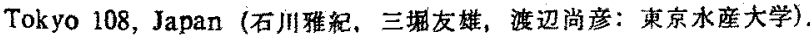

* Present address: Hokuto, Ltd., Kamimaeda, Koowa, Mihama, Chita, Aichi 470-24, Japan (加藤 传: 有级会社北斗)

*3 Present address: Chofu Gakuen Women's Junior College, Higashiyurigaoka, Asao, Kawasaki,

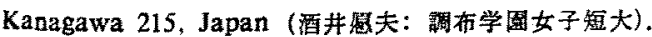


have dealt with the effects of temperature and vapor pressure of water on the cooking rate of tish bone and the drying rate of fish tissue in superheated steam.

\section{Materials and Methods}

Changes of hardness of fish bone and the moisture content of fish tissue were determined for samples cooked at $120^{\circ} \mathrm{C}$ and $130^{\circ} \mathrm{C}$ under pressures ranging from $1.2 \mathrm{kgf} \cdot \mathrm{cm}^{-2}$ to $2.7 \mathrm{kgf} \cdot \mathrm{cm}^{-2}$ : in the present paper, pressure is measured as absolute pressure.

The cooking system used in the present experiment is schematically drawn in Fig. 1. Steam was generated in a boiler by three $6 \mathrm{~kW}$ electric heaters and supplied to a steam cooker. Because the steam in the boiler was "wet" (which means the steam is satureated and contains a small amount of entrainments), the steam was dried to be super heated steam by adiabatic expansion at the pressure reduce valve $\left(V_{\theta}\right)$. The temperature and the pressure in the steam cooker were monitored and controlled by two parameters; the temperature in the boiler and the adiabatic pressure ratio at $V_{6}$.

The test piece was made from mackerel obtained from local commercial sources. Mackerel were stored at $-25^{\circ} \mathrm{C}$ until they were thawed at room temperature before use. The section of a fish used in this experiment is illustrated in Fig. 2: a fish meat bar of about $40 \mathrm{~mm}$ length with a cross section of $7 \mathrm{~mm} \times 7 \mathrm{~mm}$, in which a spine was embedded along the bar at the center of the cross section.

Each test piece was weighed with an aluminum boat of known weight before cooking. Ten to twenty test pieces on aluminum boats were placed in the steam cooker which had been heated in advance to the experimental temperature. At every sampling time, five test pieces on aluminum boats were taken out of the cooker, cooled at room temperature, and weighed. The spine was carefully picked out from the cooked test piece and the hardness was measured. ${ }^{\text {) }}$ The moisture content of the cooked fish meat was calculated from the weight loss after drying at $70^{\circ} \mathrm{C}$ at $100 \mathrm{mmHg}$ for 24 hours. ${ }^{12)}$

The apparatus and method for the measurement of hardness were similar to those described in the previous papers..$^{5-8}$ ) The hardness was defined as the cutting force, $F(\mathrm{kgf})$, divided by the cutting width $w(\mathrm{~mm})$. The cutting force was defined as the maximum load applied on the razor blade when the spine had been cut.

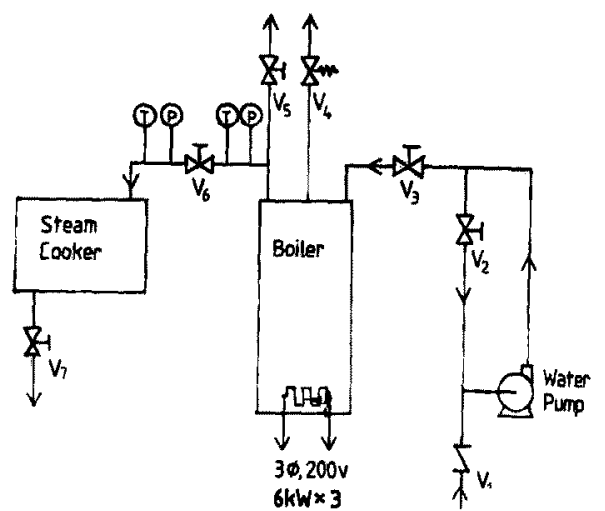

Fig. 1. A schematic diagram of the steam cooking system used in the present experiments. $V_{1}$ : check valve, $V_{1}, V_{3}$ : water control valve, $V_{4}$ : safety valve, $V_{B}$ : purge valve, $V_{\theta}$ : steam control valve, $\mathrm{V}_{7}$ : outlet valve.

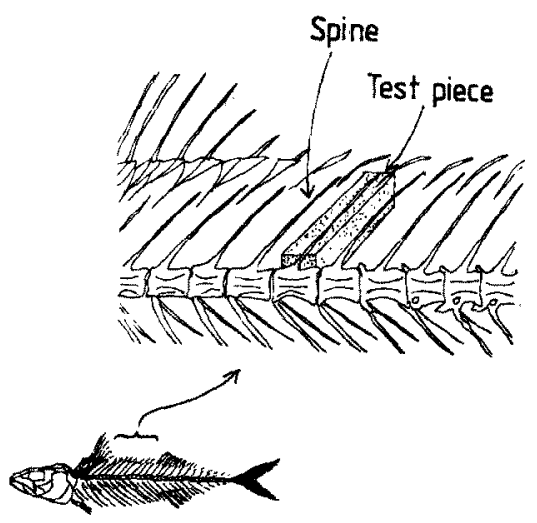

Fig. 2. A test piece of mackerel spine.

\section{Results and Discussion}

The changes of hardness of spines were measured for samples cooked at $120^{\circ} \mathrm{C}$ and $130^{\circ} \mathrm{C}$ under vapor pressures in the range from $1.2 \mathrm{kgf} \cdot \mathrm{cm}^{-8}$ up to $2.7 \mathrm{kgf} \cdot \mathrm{cm}^{-2}$ The drying rate of fish meat was examined by the change of moisture content of fish meat at $130^{\circ} \mathrm{C}$ under pressures in the range from $1.6 \mathrm{kgf} \cdot \mathrm{cm}^{-2}$ up to $2.7 \mathrm{kgf} \cdot \mathrm{cm}^{-2}$

The moisture contents of mackerel meat after cooking at $130^{\circ} \mathrm{C}$ were smaller than those before cooking for every sample (Table 1). The loss of mositure during SHSC varied from $2.5 \%$ to $7.9 \%$. Scorching or excessive drying of the surface of the test piece were not observed. Since the fish bone in the test piece was softened sufficiently to be edible under the present experimental conditions, 
Table 1. Moisture content of Mackerel meat before and after cooking at $130^{\circ} \mathrm{C}$ by superheated steam

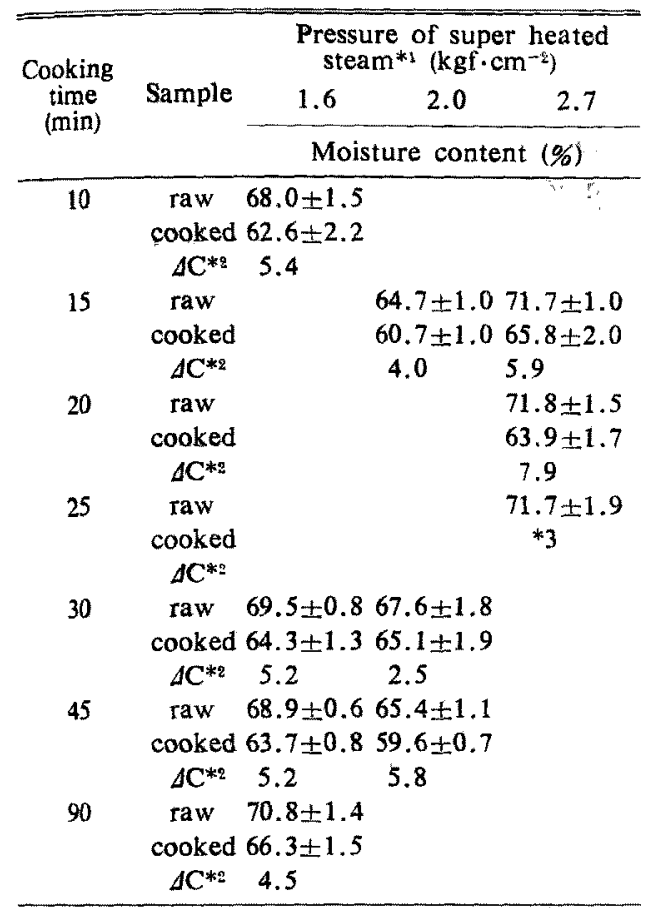

-1 Pressure is represented by the absolute pressure.

-2 Difference between moisture conent of raw sample and that of cooked sample.

* The data were lost by a mishandling in the experiment.

it is evident that the fish bone can be softened by SHSC without causing excessive drying.

The changes of hardness of mackerel spine cooked at $120^{\circ} \mathrm{C}$ and at $130^{\circ} \mathrm{C}$ are drawn in Figs. 3 and 4: the relative hardness is defined as the ratio of the hardness of cooked fish bone to that of raw fish bone.

Since the logarithm of the relative hardness decreased in proportion to the cooking time in every experiment (Figs. 3 and 4), the cooking of fish bone by super-heated steam can be referred to an apparent first-order reaction; which is similar to the cooking of fish bone in hot water ${ }^{5,8,82}$ and in hot acetic acid solutions. ${ }^{5,7,8)}$

From the results of preliminary organoleptic experiments, relative hardness of $1 / 50$ was enough soft to eat; the required cooking time is about $30 \mathrm{~min}$ at $130^{\circ} \mathrm{C}$ under the pressure of $2.7 \mathrm{kgf}$. $\mathrm{cm}^{-2}$ or about $60 \mathrm{~min}$ at $120^{\circ} \mathrm{C}$ under the pressure of $1.9 \mathrm{kgf} \cdot \mathrm{cm}^{-2}$.

The effect of the pressure of super heated steam is evident at the both temperatures: the higher the

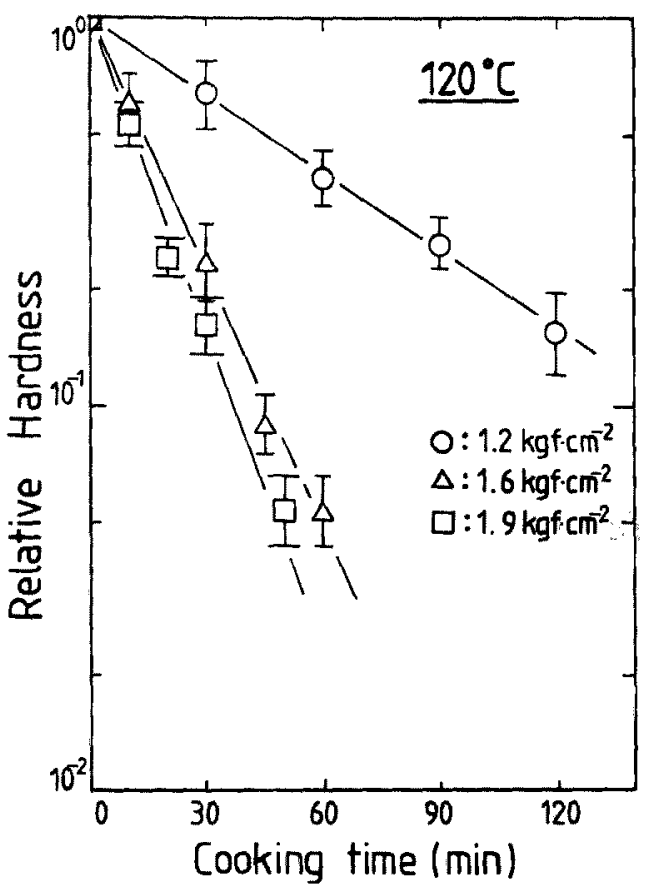

Fig. 3. The effect of vapor pressure of water in super-heated steam on the softening rate of mackerel spine at $120^{\circ} \mathrm{C}$. The relative hardness is defined as the ratio of the hardness of cooked fish bone and that of raw. fish bone.

steam pressure, the faster was the softening rate (Figs. 3 and 4). The apparent first-order rate constants were evaluated from the slopes of the fitted lines in Figs. 3 and 4. To examine the quantitative effect of the steam pressure on the softening rate of fish bone, the logarithm of the softening rate constants were plotted against the logarithm of the steam pressure (Fig. 5). All the data points settled in the vicinity of a single line in Fig. 5; apparently, this seems to imply that the softening rate constant depends on the pressure and not on the temperature of the super-heated steam.

Although the data showed a fair correlation (Fig. 5), interpretation is not so simple. The actual dependence of the rate constant on pressure is regarded as small, since the softening reaction can not be considered to be a reaction which is accompanied with a large volume change such as a certain gas phase reaction. Furthermore, it is peculiar that the difference in temperature by $10^{\circ} \mathrm{C}$ did not affect the correlation in Fig. 5. The 


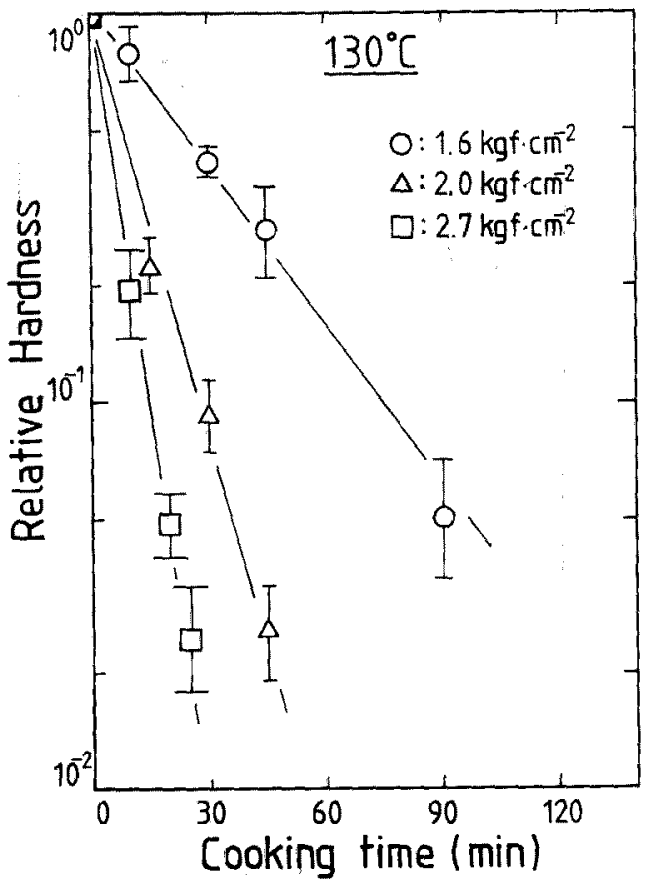

Fig. 4. The effect of vapor pressure of water in super-heated steam on the softening rate of mackerel spine at $130^{\circ} \mathrm{C}$. The relative hardness is defined as the ratio of the hardness of cooked fish bone and that of raw fish bone.

reported activation energy of the softening of mackerel spine cooked in hot water ${ }^{5,8,8)}$ or in hot acetic acid solutions ${ }^{5,7,83}$ ranged from $61 \mathrm{~kJ} \cdot \mathrm{mol}^{-1}$ to $93 \mathrm{~kJ} \cdot \mathrm{mol}^{-1}$; these data indicate that the softening rate of mackerel spine at $130^{\circ} \mathrm{C}$ is 1.6 times or 2.0 times faster than that at $120^{\circ} \mathrm{C}$ when the fish bone is cooked in hot water or in hot acetic acid solution. Therefore, it is safe to consider that the correlation does not signify a direct dependence of the softening rate on the vapor pressure but it connotes some hidden correlation between the vapor pressure and some unmentioned parameter which affects the softening rate.

According to the results of studies on the drying rate of water in super-heated steam at atmospheric pressure, ${ }^{18,14)}$ the temperature of liquid phase water was the saturation temperature in superheated steam which is $100^{\circ} \mathrm{C}$. Since the saturation temperature of the super-heated steam depends only on the pressure of the steam, the correlation between the softening rate and the vapor pressure of the super-heated steam (Fig. 5) may

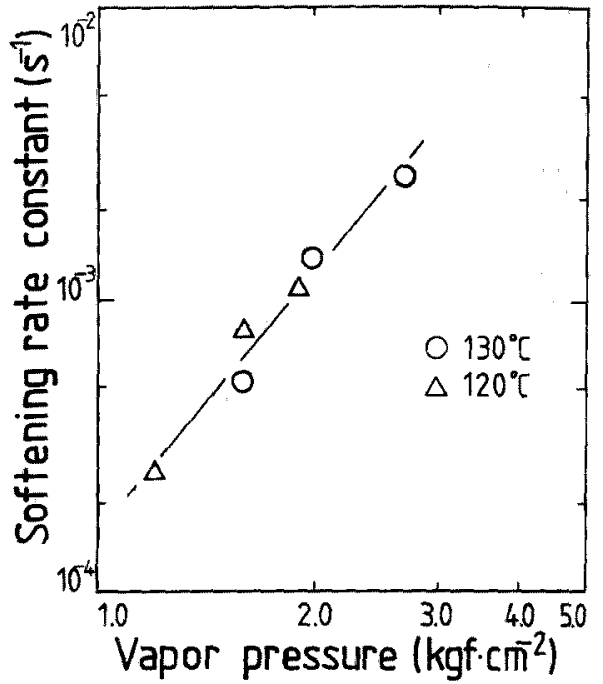

Fig. 5. The correlation between the softening rate constant and the vapor pressure of water in super-heated steam. $\log \left(k\left[s^{-1}\right]\right)=-3.78+$ $2.90 \cdot \log \left(P_{s}\left[\mathrm{kgf} \cdot \mathrm{cm}^{-2}\right]\right), k$ : the softening rate constant $\left(s^{-1}\right), P_{s}$; the vapor pressure of the super-oeated steam $\left(\mathrm{kgf} \cdot \mathrm{cm}^{-2}\right)$.

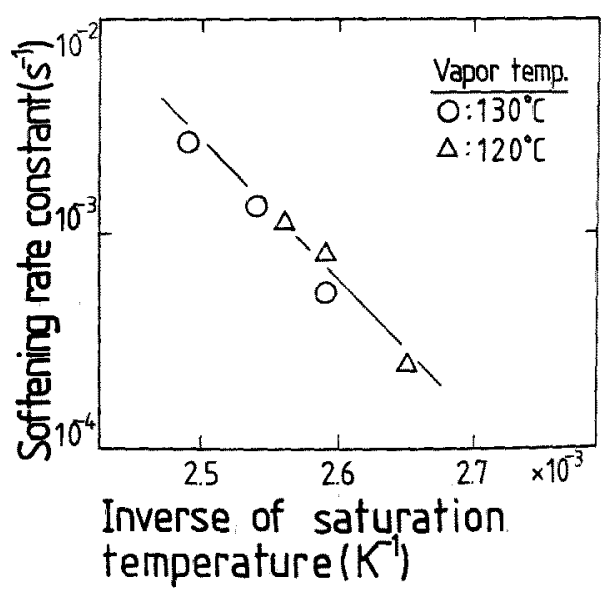

Fig. 6. The correlation between the softening rate constant and the inverse of the satura. tion temperature of super-heated steam. $\log \left(k\left[\mathrm{~s}^{-1}\right]\right)=12.2-5.96 \times 10^{\mathrm{s}}\left(1 / T_{s}[K]\right), \quad k ;$ the softening rate constant $\left(\mathrm{s}^{-1}\right), T_{s}$ : the saturation temperature of the super-heated steam.

be interpreted as the temperature dependence of the softening rate of fish bone.

The observed softening rate constants are plotted against the inverse of the saturation temperature of the super-heated steam (Fig. 6). A 
fair correlation is obtained (Fig. 6). An apparent activation energy of $1.1 \times 10^{2} \mathrm{~kJ} \cdot \mathrm{mol}^{-1}$ can be calculated from the slope of the fitted line in Fig. 6. This value is within the range of the previously reported activation energy of softening reaction of fish bone $\left.\left(61 \mathrm{~kJ} \cdot \mathrm{mol}^{-1}-113 \mathrm{~kJ} \cdot \mathrm{mol}^{-1}\right) .5-8\right)$

\section{References}

1) H. Spencer and L. Kramer. Trace Minerals in Food (Food Science and Technology ser. 28), Marcel Dekker INC., New York, 1988, pp. 95-115.

2) D.D. Duxbury: Food Processing, Oct. 110 111 (1986).

3) Food Engineering INT'L., Dec. 17-18 (1986).

4) Food Processing, 56, Apr. (1986).

5) H. Watanabe, M. Takewa, M. Takai, and Y. Sakai: Nippon Suisan Gakkaishi, 51, 20472050 (1985).

6) M. Ishikawa, S. Mori, H. Watanabe, and $Y$. Sakai: J. Food Proc. and Prese. 11, 277-287
(1987).

7) M. Ishikawa, S. Mori, H. Watanabe, and $Y$. Sakai: J. Food Proc. and Pres. 13, 123-132 (1989).

8) M. Ishikawa, S. Mori, H. Watanabe, and Y. Sakai: Shokuhin Kagaku Kogaku-2 (ed. by T. Yano), The Society of Chemical EngineerTokyo, 1988, pp. 34-38.

9) K. Hatae, T. Sato, and F. Yoshimatsu: Kaseigaku Zasshi, 31, 88-93 (1980).

10) I. Hirayama and Y. Yamauchi: Shokuhin Kogyo, 26, 66-72 (1983).

11) T. Nomura and T. Hyoudou: Shokuhin Kogyo, 29, 63-68 (1986).

12) C. Tsutsumi: Shokuhin Bunsekiho, Korin, Tokyo, 1982, pp. 8-10.

13) R. Toei, M. Okazaki, K. Kubota, K. Ohashi, K. Kataoka, and K. Mizuta: Kagaku Kogaku, 30, 43-49 (1966).

14) T. Yoshida and T. Hyodo: Ind. Eng. Chem. Process Dis. Develop., 9, 207-214 (1970). 